\title{
SLOVENSKI SPOMIN NA SOŠKO FRONTO
}

\section{SLOVENIAN MEMORY OF THE ISONZO FRONT}

Povzetek Slovenski vojak na soški fronti je imaginarna celota, ki jo sestavljajo zelo različni ljudje po narodnosti Slovenci z različnimi vojaškimi položaji, doživetji in stališči do vojne, države ter celo domovine. Take omejitve je v spoznavnem procesu o položaju in čustvovanju slovenskega vojaka nujno treba upoštevati, da ne posplošujemo posamičnih izkušenj in zaradi strukture virov ne zapadamo $\mathrm{v}$ motivacijske ter propagandne vzorce tedanje dobe. Kljub temu je mogoče sklepati, da je slovenski vojak prenašal in doživljal vse tegobe vojaškega življenja, značilne za bojevanje na razmeroma stabilnih frontnih črtah, $\mathrm{v}$ jarkih in kazematah, med pogostim topniškim obstreljevanjem ter bojevanjem iz bližine. Slovenskega vojaka je posebej opredeljeval njegov odnos do ožje domovine, ki jo je razumel kot Slovenijo ali Kranjsko, Koroško oziroma Štajersko. Ta okoliščina je pri večini slovenskih vojakov prispevala k bolj osebnemu odnosu do bojevanja na soški fronti, k lažjemu prenašanju težav življenja in bojevanja na prvi bojni črti ter k višji bojni morali.

\section{Ključne besede}

Abstract

\section{Soška fronta, vojaki, bojna morala, prva svetovna vojna.}

Slovenian soldiers on the Isonzo Front are an imaginary whole composed of very different people of Slovenian nationality with various military positions, experiences and viewpoints regarding the war, the state or even their homeland. In the cognitive process concerning the position and emotional expression of Slovenian soldiers, such restrictions should be taken into serious consideration not to overgeneralise individual experiences and fall into motivational and propaganda patterns of the era due to the structure of resources. Nevertheless, it is possible to conclude that Slovenian soldiers have dealt with and experienced in entirety the hardship of military life characteristic of the combat on relatively stable front lines, in trenches and pillboxes, during frequent gun shooting and close combat. Slovenian soldiers were especially defined by their attitude towards their close homeland, which comprised 
Slovenia or Carniola, Carinthia and Styria. With the majority of Slovenian soldiers, this circumstance contributed to a more personal attitude towards their enagagement in the Battles of the Isonzo. It also helped them soothe the hardship of life and front line combat and to develop a higher combat morale.

\section{Key words Isonzo Front, soldiers, combat morale, First World War.}

Uvod Slovenski in drugi vojaki v svojih spominih ter pričevanjih izražajo pretres zaradi bojevanja na frontah, ki je preseglo meje pričakovanega, trpljenja in bojevanja, zato je poleg tega prikaza, ki, kakor je soditi, v tej dimenziji ne presega razpona doživljanja in doživetega tudi vojakov drugih narodov, soška fronta drugačna predvsem po tem, da je bila za bojevanjem na Krasu, Goriškem in v Posočju še posebna duševna energija. Ta izvira iz njenega ozemeljskega položaja, torej umeščenosti na ozemlje, ki so ga vojaki slovenske narodnosti večinoma prepoznavali kot del svojega nacionalnega in etničnega, s to fronto pa se je povezovala narodna obrambna konstrukcija bojevati se z verolomnim Italijanom, ki hoče odvzeti slovensko zemljo.

Spomin na soško fronto delijo tudi številni civilni prebivalci na Slovenskem, čeprav so jo doživeli neposredno ali pa so bili po njenih učinkih prizadeti posredno, saj je njen vpliv segel globoko v zaledje, na večino slovenskega etničnega območja (Guštin, 2005, str. 64-70). Najbolj neposredno so številni Slovenci doživeli vzpostavljanje bojišča, ko so lahko opazovali številne izmed približno 30.000 ljudi iz Goriške, s Krasa in iz Posočja, ki so se morali precej na hitro umakniti iz obmejnih predelov, kjer so se vzpostavljale frontne črte. Spominu »goriških beguncev« se je soška fronta zarisala še globlje, saj so bili pretežno kmečki prebivalci prisiljeni zapustiti svoja posestva, ne le preseliti se v neznano, zasilna taborišča ali k sorodnikom, temveč so popolnoma spremenili tudi svoj način življenja (Svoljšak, 2010, str. 228-240). Kako se ne bi spomin na soško fronto vtisnil v spomin pripadnikov »prevaževalne čete« Ljubljanskega prostovoljnega gasilskega in reševalnega društva, ki so dan za dnem z ljubljanske železniške postaje prostovoljno vozili ranjence v številne improvizirane vojaške bolnišnice v mestu, med njimi in nazaj na vlake. V štirih letih so jih prepeljali 1.500.000 (ZAL 1). Tisoči in tisoči prebivalcev zahodnega ter osrednjega dela Slovenije so z zaskrbljenostjo poslušali hrumenje topniških obstreljevanj, posebej tistih najbolj skoncentriranih ob začetkih soških bitk, ki so odmevala še bolj vzhodno od Ljubljanske kotline (Guštin, 2005, str. 71). Dnevno časopisje je opozarjalo na italijansko nevarnost: »Nevarnost, ki Ti grozi od starega sovražnika, je na jugu zedinila ves jugoslovanski narod. Vidimo in vemo samo to: Avstrijska stvar je danes jugoslovanska stvar. Ta zemlja je avstrijska in jugoslovanska. Sovražnik Avstrije ne more biti nam prijatelj, kakor naš sovražnik ni bil, ni in ne bo prijatelj Avstrije. Da je z Italijanom tako, vidi celo Srb zunaj Avstrije. Cel jugoslovanski svet se danes z gromovitim vzklikom dviga in vstaja proti laški nesramnosti. Kot signal so zazvenele besede načelnika Hrvatsko-slovenskega kluba, dr. Korošca, ki je zaklical: 'Roke proč od naše zemlje in naše usode!'« (Slovenec, 25. maj 1915, str. 1). Zaradi soške fronte so bili zaskrbljeni intelektualci in politiki. Zanje je postala soška fronta dodaten 
razlog za skrb in navezavo na avstro-ogrsko državo ter vojsko, saj je soška armada varovala slovensko zaledje pred vojnim uničenjem in posredno ne le mej avstroogrske monarhije, temveč slovensko ozemlje in narodne meje (Škerl, 2007). Poleg politikov se je tudi mladi Šincov Jože iz Breginja kot Breginjc odločil za zvestobo cesarju in bil prepričan, da jih lahko le cesar in močno cesarstvo ubranita pred Italijani in njihovim kraljem, ki je silil na slovensko ozemlje. Kot Breginje se je zavedal, kaj pomeni biti pod italijansko nadvlado. Spomin iz leta 1866, ko so si Italijani prilastili Benečijo in Rezijo, je bil na tem območju zelo živ (Šimac, 2002, str. 194).

Še bolj neposredno so jo doživljali in se je nato spominjali slovenski vojaki. Za slovenskega vojaškega obveznika, mobiliziranega vojaka leta 1914 in v prvih mesecih leta 1915, je bila soška fronta njegova druga fronta za Galicijo ali Karpati. Na fronti že preizkušeni vojaki Slovenci so v veliki večini prišli na soško bojišče šele v začetku poletja leta 1915. Do tedaj so bili v prvem ešalonu, ki je prišel na fronto, predvsem rezervisti in vojaki, ki so čakali, da popolnijo svoje matične frontne enote, torej nadomestne bataljone. Zanje je bilo doživeti soško fronto nekaj drugega kot za frontne vojake za njimi. Razpoloženje ob izbruhu vojnih sovražnosti z Italijo je vsaj pet let pozneje nazorno opisal Ivan Matičič, vojak 27. domobranskega pehotnega polka, ki se je maja 1917 preimenoval v 2. gorski strelski polk:

»Deveti maršbataljon našega polka je moral na goriško fronto, ker se je Italija izneverila svoji zaveznici Avstriji. Klatili smo se nekaj tednov okrog Tolmina in kopali strelske jarke. Ko pa je bila vojna napoved že neizogibna, smo šli 20. maja 1915 na goro k Sveti Mariji levo od Tolmina in jo zasedli. In na binkoštno nedeljo zjutraj ob treh dobimo kratko telefonsko sporočilo: 'Danes od polnoči smo z Italijo v vojnem stanju. Pripravite se!' Pretresla nas je ta nepričakovana vest. Spogledali smo se in se bridko nasmejali. Nadporočnik Ringel, ki je bil videti pogumen mož, a jo je nazadnje le popihal k trenu (pratežu, op. a.), je pričel žugati s pestmi: 'Hvala Bogu! Vendar je prišla prilika, da se bomo krvavo maščevali za vse zahrbtne intrige in zločine, ki so nam jih prizadejali! Čakajte, vi laški hinavci, vi ničvredni ščurki, dobili jih boste, čeprav nas je malo! Začnimo fantje!'« (Hmelak, 1968, str. 36-37).

\section{SLOVENSKI VOJAK}

Kdo je bil slovenski vojak na soški fronti? Tako kot drugi si tudi slovenski vojaki bojišč niso izbirali in je bila njihova uvrstitev na soško fronto povezana $\mathrm{z}$ ukazi vojaških poveljstev, ki so enote razporejala med tremi frontami, vzhodno, balkansko in jugozahodno, ki jih je avstro-ogrska vojska morala vzdrževati. V dveh letih in pol, kolikor je ta trajala med morjem ter Rombonom, je bilo na posameznih točkah te 90 kilometrov dolge fronte več izrazitih zgostitev slovenskega vojaštva. Najprej so bili v skrajni sili nadomestni bataljoni slovenskih polkov, nato že poleti leta 191527. domobranski pehotni polk, ki je bil večino časa med letom 1915 in oktobrom 1917 nameščen v Zgornjem Posočju, 17. pešpolk, ki je bil na Krasu, dokler ga spomladi leta 1916 niso premestili med enote, ki naj bi izvedle velik napad v beneško ravnino in se nato ni več vrnil na soško fronto, 87. pešpolk, ki je bil na goriškem odseku fronte, 
7. pešpolk in 47. pešpolk, torej večina »slovenskih polkov«, temeljnih pehotnih enot, ki so vključevale največje koncentracije vojakov s slovenskega etničnega območja in so vojaško spadale v graški korpus. Le Primorcev je bilo med njimi manj, saj so ti štabi 97. pešpolk zaradi italijanskega vojaštva v njem vso vojno uporabljali na vzhodni fronti. Slovenski vojaki, tudi oficirji, so bili na soški fronti še med različnimi narodnostmi kot pripadniki artilerijskih, prevoznih in drugih posebnih enot, celo med piloti letalske flote so bili (Guštin, 2006, str. 138-139). Govorimo lahko torej o precej različni, toda hkrati celoviti in množični vojaški izkušnji slovenskega vojaka na soški fronti. Marsikateri jo je tudi zapisal in nam jo posredoval. Do bolj natančnih analiz, ki jih bo omogočila baza podatkov o padlih vojakih s slovenskega ozemlja, bo ostalo odprto vprašanje, ali je bila soška fronta tisto bojevališče velike vojne, na katerem je padlo največ slovenskih vojakov. ${ }^{1}$

\section{SPOMINJANJE IN DOŽIVLJANJE PRVE SVETOVNE VOJNE}

Velika vojna je v svoji vseobsežnosti in preseganju meja do takrat znanega ter mogočega nehote sprejela nase tudi poslanstvo velike opismenjevalke (Svoljšak, 2011, str. 523). Vojaki, ki so bili večinoma z osnovnošolsko izobrazbo dovolj pismeni, so si začeli na bojnem polju zapisovati svoje doživljanje vojne in urejati zadeve doma. Med viri o veliki vojni je tako ostalo precej pisem vojakov s front in dnevniških zapisov. Pisanje pisem je postalo priljubljena in tudi edina mogoča oblika sporazumevanja s svojim civilnim mikrosvetom, družino ter prijatelji. Višjim, bolj izobraženim in pismenim slojem so se v pisanju torej pridružili tudi preprosti ljudje. Oboji so v pismih sporočali svoje želje, hrepenenja in stiske ter tako vzdrževali stik z domačimi. Tudi za najbolj togimi in neekspresivnimi izrazi je mogoče zaznati stiske, strahove ter upanje njihovih piscev (Luthar, 2000, str. 17). Lahko bi rekli, da so bile razlike med stanovi v intimnem doživljanju vojne zabrisane. Podobno je z dnevniškimi zapisi vojakov in njihovih bližnjih. Luthar navaja, da je bilo pisanje namenjeno lažjemu premagovanju grozot in napetosti ter iskanju racionalnosti v vojnem dogajanju. Pisanje naj bi vojakom omogočilo ohraniti občutek intime v množici. Po psihoterapevtskih predpostavkah naj bi bilo pisanje sredstvo za reševanje osebne krize in izraz obupa ter želje, da bi si posameznik izboljšal osebni položaj, predvsem pa, da bi se znebil čustvenega pritiska. Pisanje dnevnika je pomenilo umik v svet, ki je prenesel grozote vojne, in jih je ohranjalo pri zdravi pameti (Luthar, 2000, str. 529). Prav tako premišljevanje o svoji stiski je veliko ljudem pomagalo preživeti vojno. Dnevniki so izčrpnejši vir za rekonstrukcijo miselnosti in intimne zgodovine sodobnikov kot pisma. Dnevniki namreč predstavljajo necenzurirano refleksijo dogajanja in nam $\mathrm{v}$ nasprotju $\mathrm{z}$ bolj ali manj cenzuriranimi pismi povedo veliko več o emocionalnem in tudi materialnem življenju med prvo svetovno vojno (Luthar, 2000, str. 20).

Projekt Zbiranje podatkov o vojaških žrtvah prve svetovne vojne na Slovenskem se je začel leta 2015, baza pa bo javno dostopna od novembra 2018. Pri projektu sodeluje 16 ustanov in posameznikov, koordinator pa je

Inštitut za novejšo zgodovino. 
V nasprotju s tem je v vojnih spominih opisana vojna, kot se je avtorji spominjajo s časovne razdalje. Prav to je bilo pomembno pri njihovem oblikovanju. Zaradi nje se v poznejših spominih ne kažeta tak obup in srd nad doživljanjem vojne kot v sprotnih dnevniških zapisih. Vojna izkušnja je bila predvsem izkušnja mladega človeka, ki je v vojni čutil življenje in smrt z drugačno intenzivnostjo kot v miru. Za razumevanje sprememb, ki jih vojna povzroči človeku, sta namreč potrebna čas in vzpostavitev distance do tistega, česar se pisec o sebi spominja (Svoljšak, 2011, str. 527-528).

Avtobiografski viri ne omogočajo celovitega vpogleda v vojne izkušnje, temveč fragmentaren vpogled v miselni svet, čustvovanje in doživljanje piscev. Dnevniki, pisma in spomini nam veliko povedo tudi o okolju, v katerem je vojak doživljal svojo vojno izkušnjo, kar pomeni, da so zaznamovani tudi s segmenti objektivnega dogajanja (Verginella, 2005, str. 178).

\section{SLOVENSKI VOJAKI O SOŠKI FRONTI}

Slovenska vojna pričevanja so predvsem zgodbe vojakov, ki so služili v tedanji avstro-ogrski vojski. Pisana so brez slabe vesti ali opravičevanja zaradi službe v »tuji« vojski. Svoje bojevanje so razumeli kot del vojne službe, ki so jo zvesto in temeljito opravljali ne glede na bojišče (Svoljšak, 2009, str. 314). Gledano širše so teže sprejemali dejstvo, da morajo biti na bojiščih v Srbiji in Rusiji. V začetnih bitkah v Galiciji so avstro-ogrski vojaki prvič izkusili industrijsko bojevanje. To je bilo zanje in ne le zanje nepredstavljivo (Bobič, 2014, str. 86).

Soška fronta se je razlikovala od dotedanje vojne izkušnje le toliko, kot so jo oblikovali prostor, hribi namesto ravnine in kamen namesto prhke zemlje. Pomembna je bila še moralna komponenta, ki bi jo lahko označili kot intenzivirano domoljubje in posledično izboljšana bojna morala. Izrazito zavedanje slovenskih vojakov, da se na soški fronti brani tudi ožja domovina, je spodbudila marsikaterega vojaka. Po italijanski vojni napovedi avstro-ogrski monarhiji so slovenski vojaki boj ob Soči začeli razumeti kot nujni klic k boju za domovino. Govorili so celo o »hrepenenju«, da bi šli v boj proti »Lahom«.

Andrej Dobravec, ki se je boril na balkanski fronti, vendar so ga zaradi revmatizma poslali v zaledje, je prosil domačega župnika, naj v njegovem imenu napiše pismo vojaškemu poveljstvu, da ga pošljejo na italijansko fronto. Duhovnik je prošnjo oddal S toplim priporočilom. Podobno je slovenski vojak pisal z meje z Italijo: »Slovenske krvi smo in pripravljeni smo jo preliti za slovensko zemljo, če je treba.« (Bobič, 2014, str. 86-87). To pripravljenost žrtvovati se za obrambo države, da bi obranili svoje nacionalne interese, so opazile tudi vojaške oblasti. Za slovenske vojake je bilo v avstrijskih uradnih poročilih zapisano, da so kljub jugoslovanskim željam poslušali poziv cesarja, da bi dosegli politično samostojnost kot darilo za zvestobo cesarju, in so bili z veseljem pripravljeni žrtvovati vse, tudi zadnjo kapljo krvi. Povsod so se bojevali in prelivali kri slovenski fantje za domovino. Držo posameznih slovenskih enot so označili kot neoporečno (Svoljšak, 2009, str. 299). 
Z italijansko vojno napovedjo in prvimi napadi na avstro-ogrske položaje za mejo se je začel »krvavi ples« z novim sovražnikom, ki ga ni bilo mogoče podcenjevati. Avstro-Ogrska je dobila še eno precej dolgo fronto in italijanska vojna napoved je kljub tihim slutnjam ter ugibanjem prišla nepričakovano. Poglavje, ki sledi, je vpogled v oseben svet posameznikov, ki so se bojevali na soškem bojišču in svoje doživljanje vojne zapisovali v nam dostopne dnevnike.

Vojaki, ki so imeli pred seboj primerjavo, so soško fronto doživljali kot drugačno, še zahtevnejšo in nevarnejšo. Izkušeni avstro-ogrski vojaki, ki so imeli izkušnje z boji v Galiciji in Karpatih, so vojno na soškem bojišču opisovali s spoštovanjem ter čudenjem obenem. »Možje in častniki, ki so bili na gališkem bojišču, pravijo, da kaj tako strašnega, kakor se tu vidi, tam niso doživeli, « je zapisal topničar Mihael Mohor (Svoljšak, 2014, str. 16). Kaj je bilo tako strašno? Na soškem bojišču je potekala bojna črta po visokogorju in čez Kras, kjer je bil pritisk napadalcev najhujši. Na kamnitem kraškem terenu so imeli branilci slabe zaklone, njihovo kopanje je zahtevalo precej večje napore in prešibke enote so komaj zadoščale za obrambo. Pomanjkljiva prometna infrastruktura, ki jo je vojska šele na hitro gradila, je slabšala stik z zaledjem in pravočasno ter zadostno oskrbo. Kamnit kraški teren je še povečeval učinke topniškega obstreljevanja. Ofenzive so se na soškem bojišču začele z večurnimi topniškimi pripravami, sledili pa so juriši pehote čez vmesno polje, prepredeno z žičnimi ovirami. Vojaki so napadalce poskušali ustavljati z zadnjimi močmi v bojih iz bližine. Preživeli vojaki so ponoči utrjevali porušene okope in kopali zaklone. Hudo težavo na kraškem odseku je pomenilo nenehno pomanjkanje vode. Preskrba s hrano vojakov na prvi bojni črti je bila slaba in neredna. Podnevi se branilci niso premikali, da ne bi izdali svojih položajev. Branilci ob Soči so imeli poleg nenehnega italijanskega obstreljevanja večkrat težave tudi z vremenom. Njihova kritja je uničeval močen dež z vetrom. Hudourniki so jih uničevali in odnašali. Kadar je streljanje malo ponehalo, so vojaki popravljali strelske jarke (Hrovat in drugi, 2015). ${ }^{2}$ Kar je bilo porušeno, so poskušali vojaki ponoči popraviti. Italijanska artilerija je namreč ponoči mirovala, so pa branilce ogrožale patrulje italijanskih strelcev, ki so ležali zariti v zemljo, večkrat le nekaj metrov pred branilci, in vso noč streljali. Kritja so bila v razvalinah, izgube velike, ranjenci so ječali in prosili vode. Ivan Matičič je zapisal, da je bilo njihovo stanje nevzdržno (Hmelak, 1968, str. 65, 87). Vojaki so komaj čakali, da so po 14 dneh ali treh tednih na prvi bojni črti dobili zamenjavo in odšli v zaledje (Videmšek, 2014).

\footnotetext{
Nekdanji vojak Avstrijec Hans Pölzer je v svojih spominih opisal zadnje tri dni, ki jih je prebil ob Soči. Pripadniki 6. pehotne divizije (6.K.u.K. Infanterie Division), med katerimi je bil tudi Hans Pölzer, so v bližino Prvačine prispeli z vlakom med 28. oktobrom in 1. novembrom. Od tam so zasedli položaje na frontni črti in tako od 10. novembra do 14. decembra 1915 sodelovali v 4. soški bitki. Ob zasedbi položajev je opisal stanje obrambnih jarkov. Lesene deske in ostrešja iz klobučevine niso mogli zdržati nenehnega topniškega obstreljevanja. Na tem območju je bil v deževnem obdobju, zato je pretresljivo opisal dogajanje v komunikacijskih jarkih. Po jarkih se je pretakala gosta in oljnata blatna brozga rdečkasto rjave barve, ki je med dežjem curljala iz vsake skalnate razpoke. V marsikaterem jarku se je je nabralo toliko, da je odraslemu možu segala čez glavo, v njej pa so plavali deli razpadajočih človeških trupel (Pölzer, 2011, str. 4-15).
} 
Obremenjujoča je bila velika intenzivnost spopadov, zlasti na Krasu. Italijansko topništvo je močno obstreljevalo prav oskrbovalne linije. Težavo so poskušali reševati z nočno dostavo hrane (Stergar, 2015, str. 4-5). Franc Grošelj, ki je bil na soški fronti sanitejec in pripadnik vojaške zdravstvene enote, je pripovedoval, da so v času bitk jedli le enkrat na dan, navadno zvečer, približno ob 23. uri. Kadar je streljanje malo ponehalo, so vojaki popravljali strelske jarke (Hrovat in drugi, 2015).

Veliki težavi sta bili tudi preskrba z vodo in žeja, saj je na kraškem območju ter tudi v visokogorju primanjkovalo vode. Kljub zastraženim vodnjakom in prepovedi pitja nečiste vode so glede na pričevanja vojaki pili vsakršno vodo, zaradi česar so se širile nalezljive in nevarne črevesne bolezni. Vojaške oblasti so začele graditi vodovode in si prizadevale redno dovažati vodo, toda preden jim je to uspelo, so minili meseci (Štepec, 2016, str. 33). ${ }^{3}$

Obremenitve na bojišču so marsikaterega branilca privedle na rob blaznosti in obtoževanja tako Avstrije kot Italije. Prva naj bi jih gnala v smrt, druga jih je pobijala (Hmelak, 1968, str. 88). Slovenski branilci so prezirali italijanski ozemeljski pohlep. V knjigi Ivana Matičiča lahko preberemo izlive ogorčenja: »Kam le ta hudič laški rine? Saj se mora človeku že do grla gabiti ta požrešnost. Svoje ljudi je imel že prvi dan odrešene vse. A čemu se zajeda naprej v našo zemljo? Saj nas vendar ne misli odrešiti? «(Hmelak, 1968, str. 88). ${ }^{4}$

Po italijanski napovedi vojne so prišli na površje (slovenski) stereotipi o »laških verolomnežih« (Stergar, 1996, str. 71). Glede na to, da so bili vojni cilji Italije znani in je bila približno znana tudi vsebina londonskega pakta, je razumljivo, da so predsodki do Italijanov dobili trdno podlago in novo nadgradnjo. Slovenci in tudi Hrvati ter drugi južni Slovani iz monarhije so se upravičeno počutili ogrožene in so kar tekmovali v obsodbah italijanskih zahtev. Mnenje o Italijanih kot slabih vojakih, ki ni bilo le slovensko, je bilo v tistem času priljubljena tema. Trije najbolj izraženi slovenski stereotipi o zahodnih sosedih so bili, da so Italijani verolomneži, ki jim ne moremo zaupati, in slabi vojaki ter da je njihova vojska komaj vredna tega imena. Ti stereotipi so prišli na dan tudi med branilci na soški fronti. Poznejši zgodovinski dogodki so jih le še okrepili, tako da so prisotni še danes (Stergar, 1996, str. 72-73).

Zanimiv odmik od stereotipov o italijanskem nasprotniku in od vojne morije je vojni roman Prežihovega Voranca Doberdob. V njem pisatelj 20 let po koncu vojne ruši mit

\footnotetext{
Pomanjkanje vode je bila splošna težava vojskujočih se strani tudi na drugih bojiščih. Zanimiva je pripoved Vladislava Fabjančiča, ki se je bojeval kot prostovoljec v srbski vojski, tudi v bitki na Ceru. Zapisal je: „Pri nekem vodnjaku blizu Uba sem imel priliko opazovati in sodelovati pri ogorčeni nočni borbi za vedro (vode; op. a.). Naredniki in oficirji, ki nas niso pustili piti - odmor ni bil ukazan - so bili v hipu odrinjeni. Kdor od vojakov je imel krepkejše pesti, je pil. Midva z Jenkom (Avgust Jenko, tudi prostovoljec; op. a) sva bila med temi. Da sva jih dobila s plosko sabljo po hrbtu, naju ni preveč vznejevoljilo. Grozovita žeja je bila vsaj za čas ugašena.« (ZAL 2).

4 Vzpostavitev soške fronte je treba razumeti skozi dolgoletno nezadovoljstvo Kraljevine Italije z mejo ob Jadranskem morju. Po mnenju italijanske politike naj bi bila to ozemlja, ki jih je zasedla italijanska vojska »znotraj naravnih meja Italije«. »Odrešene pokrajine« so odražale temeljni cilj italijanske politike in razloge za poseg v vojno (Prim. Svoljšak, 2003).
} 
o junaški vojni in prikazuje zbegane ter prestrašene vojake na obeh straneh bojišča. Odnos glavnega junaka in s tem (deloma) Voranca do italijanskega nasprotnika je večplasten. Narodnostno so jima resnični sovražniki, uničevalci tega, kar jima je drago, bodoči okupatorji in zatiralci slovenske svobode, človeško in osebno pa so žrtve iste nesmiselne vojne (Kač, 2016).

Pogosto je v spominih vojakov prisotna kritika nadrejenih, predvsem zaradi njihovega vzvišenega odnosa in šikaniranja podrejenih. Tovrstne razlike postanejo razumljive, če pomislimo, da gre za družbo, v kateri so bile razlike glede na stan nekaj običajnega in samoumevnega. Vojska je bila strogo hierarhično urejena. Že pred vojno je vojaško vodstvo aktivnim in rezervnim častnikom privzgojilo občutek družbene elite, ki vojakom ukazuje, vendar se z njimi ne druži (Stergar, 2015, str. 26-27).

Vsakodnevna soočenja s smrtjo so pri posameznih vojakih vzbudila različne odzive, kar je bilo odvisno od značaja posameznika. Če so se nekateri mrzlično oklepali vere v strahu pred smrtjo, so bili drugi nekako vdani v usodo in so se zazrli vase. Ferdinand Wigele, rojen leta 1898 v Starem trgu pri Rakeku5 ${ }^{5}$ je 24. februarja 1917 zapisal v svoj dnevnik, da njegovo trenutno življenje ni vredno nič, čeprav v tistem trenutku še ni bil soočen z realnostjo soškega bojišča, temveč se je v bližini soškega bojišča le uril v bojih s sovražnikom. »V prihodnost se ne smeš ozirati, saj si lahko že naslednji dan mrtev, « je zapisal (ZAL 3), smrti pa ni imel za nekaj grozečega. Od tega se je bolj bal, da bo invalid in odvisen od drugih. V takem primeru bi raje sam naredil konec. Soočen s pričakovanjem morebitne smrti se ozira v preteklost. Pretekli čas idealizira. Govori o krasnih časih, ki jih ni znal izkoristiti. Žal mu je, da ni preprosto živel (ZAL 3). Ob nenehnem soočenju s smrtjo in strahom se zdi preteklo življenje tako preprosto. Idealiziranje preteklosti vzbuja v človeku občutek neizživetosti.

8. februarja 1917 je udeležencem »Off(izzier) Fortbildungskurs«, torej oficirskega tečaja, v Št. Petru na Krasu vodja prebral ukaz italijanskega vojaškega vodstva italijanskim vojakom kot opozorilo o resnosti položaja. Ukaz je namreč predvideval, da bo naslednja italijanska ofenziva mogoče zadnja $v$ tej vojni. $V$ ta namen je italijansko vojaško vodstvo pričakovalo od vsakega svojega vojaka, da opravi svojo dolžnost in vse, kar je v njegovi moči. Italija je bila prepričana v svojo absolutno premoč. 11. februarja je polkovni zdravnik tečajnikom predaval o različnih boleznih na bojišču in ob tej priložnosti izjavil: »S tega bojišča ne pride nihče živ v Hinterland.« (ZAL 3). 12. februarja je Wigele zapisal, da priprave kažejo na »nekaj velikega« in da bo verjetno moral tudi on kmalu »v ogenj«. Čutil se je pripravljenega, toda hkrati

\footnotetext{
Ferdinand Wigele je bil 28. aprila 1916 potrjen na naboru. Dodeljen je bil 17. pěspolku. Ohranjeni dnevnik obsega čas od leta 1916 do marca 1918. Na začetku prve knjižice svojega dnevnika je zapisal, da ne piše za druge, temveč le zase, da bi se v starosti, če jo dočaka, lahko spominjal mladosti. Če bi umrl na bojičču, je prosil najditelja, da zapiske takoj uniči, domačim, katerih naslov je pripisal, pa sporoči njegovo smrt. Ko so ga Italijani 19. junija 1918 zajeli, so mu očitno odvzeli zapiske, ki obsegajo čas po 20. marcu 1918, tako da kaže, da jih je obnovil po spominu.
} 
si je želel še enkrat obiskati dom in Cirilo (verjetno simpatijo; op. a.), potem pa, »če že mora biti, grem«. (ZAL 3). 26. februarja je bila njegova enota prestavljena na tehnični »Übungsplatz« na Primož nad Pivko, kamor sta prišla tudi vrhovni poveljnik soške fronte Svetozar Borojević von Bojna in bataljon častnikov (ZAL 3). V začetku marca je bil Wigele še vedno na Primožu. Čas tam ni bil namenjen le urjenju, temveč tudi sprostitvi. Ob tej priložnosti je opisal neki večer, ko sta vino in glasba raznežila trda vojaška srca. Stotnik Popp, ki je očitno pripadal »I. R. 43. Marsch«, je ob zvokih glasbe vstal in se spominjal 8. soške bitke. V boj je šel s 600 vojaki in 16 častniki. Vrnilo se je le 15 vojakov in častnik (ZAL 3). Take pripovedi drugih so Wigeleju potrjevale zavedanje o minljivosti vsega in njegovo čakanje, da pride tudi on na vrsto. V dnevniških zapisih se opazi njegovo prepričanje, da prihod na bojišče pomeni konec življenjske poti. 14. marca je bil Wigele v Škrbini dodeljen »4. Feldkompaniji«. Izrazil je zadovoljstvo nad dejstvom, da mu (še) ni bilo treba v strelske jarke tako kot nekaterim njegovim tovarišem. Dobil je vojaško opremo s plinsko masko in 130 »patronov«, imel pa je tudi težave z ušmi in podganami. Vzkliknil je: »O Bog, kako življenje in koliko časa bode treba tako živeti?« Bil je obupan in v tistem trenutku prepričan, da je edina rešitev smrt. Želel si je, da bi bil kmalu ranjen ali bi ga krogla zadela do smrti (ZAL 3). Ni bil še na bojišču, vendar mu je že njegova bližina vzbujala občutke groze in mešane »želje« biti ranjen ter biti ranjen do smrti. Nič, kar je videl, se mu ni zdelo več človeško.

Ob obisku pokopališča je občudoval mogočne ciprese, ki so se ponosno gibale V vetru, vendar je bil ta odmik od resničnosti kratek. Že naslednji trenutek je ob opazovanju grobov zapisal: »Blagor vam, videli niste gorja, odšli ste prej, blagor vam. Vaši sinovi pa umirajo v bližini vas ...« (ZAL 3). Ni se (še) bojeval na bojišču, vendar ga je njegova bližina silila v samouničevalno razmišljanje in »iskanje« stika s smrtjo. Smrt na pokopališču mu je dajala občutek miru, saj so ti ljudje odšli že pred vojnimi grozotami. Oziral se je okoli sebe in videl le porušene hiše. Vzkliknil je: »Prebivalci tega kraja, ostanite tam, kjer ste, da ne vidite te beračije, da ne vidite svojih domov.«(ZAL 3).

Njegovo pisanje so nenehno motili preleti italijanskih letal. Slikovito je opisal streljanje avstro-ogrske artilerije na italijansko letalo. Tudi ponoči ni bilo miru. Sovražnik je »grozno« streljal. «Presnete uši« in italijanska artilerija so mu kratile spanec.

Okoli 20. marca je bila njegova enota v Kobjeglavi, nato v Koprivi. 2. aprila je zapisal, da je bil povišan v »Zugsführerja«. ${ }^{6}$ Tega je bil zelo vesel, saj mu ni bilo treba več opravljati tehničnih del, prišil pa si je tudi našitke. Povišanje je praznoval v Sežani, kjer sta s tovarišem popila liter vina (ZAL 3). V tej fazi je bilo njegovo pisanje ponovno lahkotnejše. Opisoval je svoj vsakdan in se ni spuščal v globlja razmišljanja. Očitno mu je povišanje dvignilo moralo, hkrati pa mu je enoličen vsakdan začel presedati, saj je zapisal: »Takega pustega življenja še nisem živel,

${ }^{6}$ Prvi del besede ni jasno napisan, zato sklepamo, da gre za Zugsführerja (op. a.). 
vedno enako.« (ZAL 3). V tej fazi pisanja dnevnika se je Wigele očitno nekako distanciral od prejšnjih pogostih razmišljanj o smrti. Enoličnosti se je naveličal. Zdi se, da je bil jezen, saj nas preseneti njegov ostri zapis o novem nadrejenem »Oblt. Trattniku«. Zapiše, da je »v pravem pomenu svinja«. Tudi drugi naj bi spoznali, da ni nič kaj prida človek (ZAL 3). Za svoj osebni svet si je torej privoščil odkrito kritiko nadrejenega, kar je bilo v tedanji strogi vojaški in na sploh družbeni hierarhiji strogo prepovedano ter najstrožje kaznovano. To je bil njegov dnevnik, njegov intimni svet sredi vojnega dogajanja. Dnevniški zapisi Ferdinanda Wigeleja pričajo o dozorevanju mladega človeka, ki se je v mladostniški naivnosti prostovoljno pridružil vojakom, vendar je svojo vojaško pot končal v italijanskem ujetništvu kot trdna in prezgodaj dozorela oseba. Predčasno trdnost in prisilno dozorelost so s seboj prinesli številni vojaki.

Sklep Ko je ljubljanski župan Ivan Tavčar 28. oktobra 1917 dobil vest o ponovni avstroogrski zasedbi Gorice in zmagoslavnem prodiranju avstro-ogrske vojske v notranjost italijanskega ozemlja, je na slavnostni seji 6. novembra 1917 nagovoril mestni svet (ZAL 4). Navzoči so izrekli priznanje svojemu cesarju in vladarju Karlu, ki je avstro-ogrsko vojsko pripeljal do »popolne zmage«. Izrekli so mu vdanost in »neomahljivo« zvestobo. Ob tej priložnosti so se spomnili tudi svojega častnega meščana, vrhovnega poveljnika soške armade Svetozarja Borojevića, ki je v enajstih bitkah branil slovensko zemljo pred številnejšim italijanskim nasprotnikom. Spomin so posvetili tudi vsem vojakom, ki so se bojevali v nemogočih razmerah in žrtvovali svoje življenje za domovino. Župan in mestni svet sta izrazila ponos, da so v bojih sodelovali tudi slovenski vojaki, ki »niso nikdar omahovali in bili med prvimi $\mathrm{v}$ tistih vrstah, ki so se pehale za zmago« (ZAL 4). Zahvalo sta izrekla tudi nemškim zaveznikom.

Uspešen prodor avstro-ogrske vojske so imeli navzoči na slavnostni seji mestnega sveta za zmago nad Italijani in možnost za končni, pravični mir. Izrazili so upanje, da se v monarhiji pravica ne bo več delila različno, temveč enakopravno. Iz slovenske krvi, ki je bila prelita ob Soči, naj bi zrasla pravica. Porok za to naj bi bil cesar Karl, ki je »pravi zastopnik prave pravice« (ZAL 4). Nadaljnji razvoj dogodkov je pokazal, da so bila njihova pričakovanja, povezana z zmago na soški fronti, prevelika tako na notranjepolitičnem kot zunanjepolitičnem področju. Italija je pridobila velik del slovenskega etničnega ozemlja in Avstro-Ogrska je ostala toliko mačehovska, da so jo v trenutku poraza zapustili.

2. Guštin, D., 2005. Soška fronta in njeno slovensko zaledje. V P. Vodopivec, ur. K. Kleindienst, ur. Velika vojna in Slovenci 1914-1918. Ljubljana: Slovenska matica, str. $62-74$. 
3. Guštin, D., 2006. Slovenske enote na frontah v Evropi 1915-1918. V J. Fischer, ur. Slovenska novejša zgodovina 1848-1992 1. Ljubljana: Mladinska knjiga: Inštitut za novejšo zgodovino, str. 137-140.

4. Hmelak, I., 1968. Soška fronta. Koper: Založba Lipa.

5. Hrovat, E. Z., Mazovec, Samo, Cencelj, Gaber, Renko, Ana, 2015. Vpoklici v prvo svetovno vojno in dogajanje na soški fronti. Domžale: OŠ Rodica. http://sola-rodica.splet. arnes.si/2015/07/02/vpoklici-v-prvo-svetovno-vojno-in-dogajanje-na-soski-fronti/, 21 . 2. 2018.

6. Kač, M., 2016. »Kdo pa jih je silil v vojno, Italijane? - In kdo je silil nas? «Ob dokumentarnem filmu Valentina Pečenka Doberdob: Ungaretti-Voranc. Ljubljana-MMC RTV SLO. http://www.rtvslo.si/prva-svetovna-vojna/spomin-je-ziv/kdo-pa-jih-je-silil-vvojno-italijane-in-kdo-je-silil-nas/408264, 21. 2. 2018.

7. Luthar, O., 2000. »O žalosti niti besede«: uvod v kulturno zgodovino velike vojne. Ljubljana: Založba ZRC, ZRC SAZU.

8. Pölzer, H., 2011. Trije dnevi pekla na Soči. Ljubljana: Karantanija.

9. Svoljšak, P., 2003. Soča, sveta reka: italijanska zasedba slovenskega ozemlja (1915-1917). Ljubljana: Nova revija.

10. Svoljšak, P., 2009. Velika vojna in Slovenci. Studia historica Slovenica. 9-2/3, str. 297-316.

11. Svoljšak, P., 2011. Pisanje kot zdravilo ali oznanilo bodočim rodovom. Po slovenskih spominskih poteh velike vojne. Acta histriae. 19-3, str. 523-538.

12. Svoljšak, P., 2014. Na krvavih poljanah. Mladina: Prva svetovna vojna 1914-1918. Posebna številka, str. 12-21.

13. Stergar, R., 1996. »Lahu niti pedi naše zemlje«: slovenski pogledi na Italijane ob napovedi vojne 23. maja 1915. Kronika, 44-1, str. 69-73.

14. Stergar, R., 2015. Hrana na bojiščih prve svetovne vojne: izkušnje slovenskih vojakov. Prispevki za novejšo zgodovino, 55-2, str. 22-53.

15. Slovenec, 25. 5. 1915, XLIII, št. 116, str. 1, Za domovino - Vsi Jugoslovani edini.

16. Šimac, R. R., 2002. Kako se je začelo na Soči 1915 in končalo 1918: Brginske in druge pripovedi o prvi svetovni vojni. Nova Gorica: Grafika Soča.

17. Škerl, U., 2007. Po zadnji bitki na soški fronti: Tista krogla me ni prijela. https://www. dnevnik.si/278452, 12. 5. 2017.

18. Štepec, M., 2016. »Bedna kritja pod planoto tik nad Sočo«: v strelskih jarkih soškega bojišča 1915-1917. Zgodovina v šoli 25-1/2, str. 29-38.

19. Verginella, M., 2005. Velika vojna v avtobiografskih zapiskih slovenskih vojakov. VP. Vodopivec, ur. K. Kleindienst, ur. Velika vojna in Slovenci: 1914-1918. Ljubljana: Slovenska matica, str. 175-184.

20. Videmšek, B., 2014. »Šli smo kot teleta v klavnico, nismo vedeli, ne kod ne kam«. http:// www.delo.si/zgodbe/sobotnapriloga/sli-smo-kot-teleta-v-klavnico-nismo-vedeli-ne-kod-nekam.html, 22. 2. 2018.

21. Zlobec, A., 2008. V viharju soške. Kobarid: Ustanova Fundacija Poti miru v Posočju.

Viri $\quad$ 1. ZAL-Zgodovinski arhiv Ljubljana.

2. ZAL 1: ZAL, LJU 489, REG I, t. e. 2062, Vojna, Promet v bolnišnicah (Spitalsbetrieb).

3. ZAL 2: ZAL, LJU 307, Vladislav Fabjančič, Ljubljana, t. e. 1, a. e. 8, Čutara vode.

4. ZAL 3: ZAL, LJU 394, Ferdo Wigele, t. e. 2, a. e. 19, Dnevnik 1916-1919.

5. ZAL 4: ZAL, LJU 489, Mesto Ljubljana, Splošna mestna registratura, t. e. 2061, Vojna, Slavni mestni svet! 